\title{
The Constitution Of Pakistan (1973) And Women Rights: An Interpretation
}

\author{
Abida Perveen \\ Sheikh Zayed Islamic Center \\ University of Karachi
}

\begin{abstract}
Women Rights are part of Human Rights, which are considered important in every society. These rights are inalienable and indivisible rights held by all, and are the basic standards of equity and justice without which people cannot live with dignity. The situation of Women Rights in Pakistan is complex as a result of country's diversity, large population, its status as a developing country and a sovereign Islamic Republic as well as Islamic democracy with a mixture of both Islamic and secular laws, which include freedom of speech, freedom of thought, freedom of information, freedom of religion, freedom of association, freedom of media and freedom of assembly. The constitution of the country (1973) carries Human Rights different and this article debates certain classes with are respected in practice. The main purpose of the study is to explore the reasons why women Rights Situation in Pakistan has not been satisfactory.
\end{abstract}

Keywords: The Constitution of Pakistan (1973), Women's Rights.

$$
\begin{aligned}
& \text { تلخيص }
\end{aligned}
$$

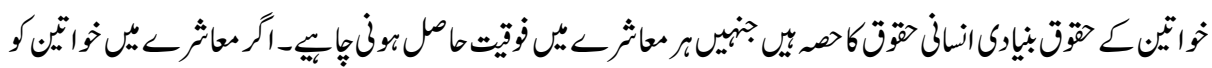

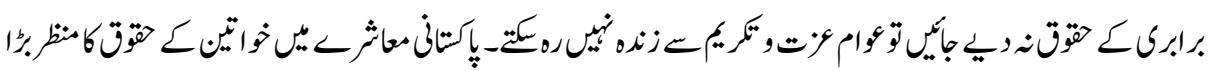

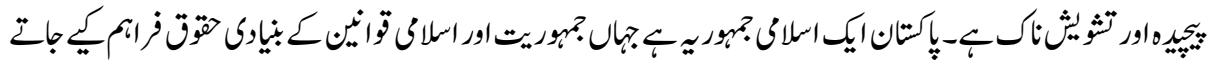

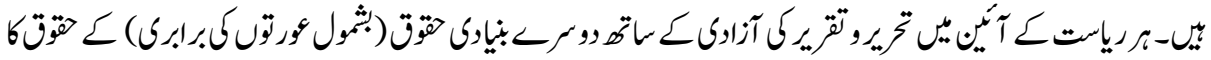

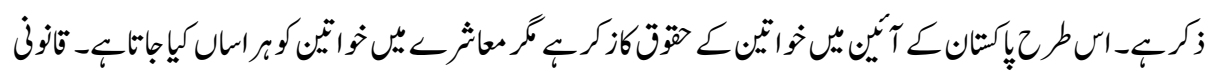

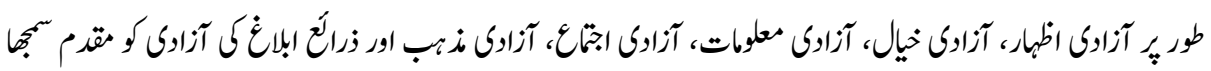

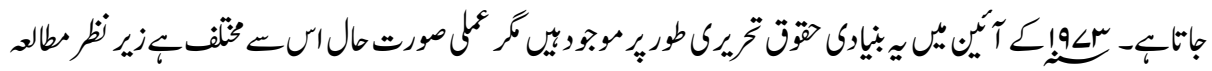

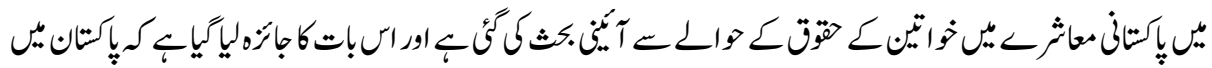

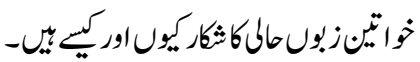

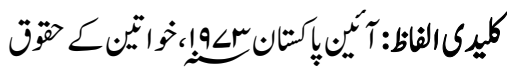




\section{Introduction}

The constitution of Islamic Republic of Pakistan makes it binding that there will be no discrimination on the basis of gender (The Constitution of Pakistan, Article 25 (2) (1973). In pursuance of this, the planning and policies for ensuring gender equality, women rights and empowerment of women have developed gradually, considering their significant contribution to sustainable socio-economic development of Pakistan. Women constitute 51 percent of the total population and 22.7 percent of the labor force (Planning Commission, 2015).

The National Policy for Development and Empowerment in Pakistan ensures women equal access to all development benefits and social services. Pakistan has pledged to promote gender equality and empowering women, improving health. Pakistan is signatory of the United Nations convention for elimination of all forms of discrimination against women. The Pakistan National Policy for Development and Empowerment also ensures women's equal access to all development benefits and social services. Despite their defined constitutional, legal and religious the status of women is under shadows.

The position of women in society is mainly determined by attitudes and behaviour towards them. Even where women's rights are recognized by civil and religious laws, in pradica, cultural traditions and men's ingrained attitudes towards women often deny them in their proper status. For example, men and women have equal rights in marriage, and in almost all Muslim countries, education for both boys and girls is obligatory. In addition, some countries have introduced laws to offer better job opportunities for women in public sector. However, these laws have not generally made much difference to the status of women, and little will charge as long as the attitudes and behaviours towards women in a society remains a plethora.

\section{Related Research Work}

The researcher has gone through a plethora of different relevant studies during the writing of this paper. The purpose is to view the empirical literature related to present article. The constitution of Pakistan (1973) is supreme law of the country. Article 8 to 28 of the constitution describe the fundamental human rights which are available to the citizen of Pakistan both men and women. The executive is bound to implement these rights while the judiciary is bound to take article of any violations and provide redress on individual complaints of any gross violations of a collective rights.

Timothy, M. Shaw stated that there is an incredibly widespread assumption that human rights is a western concept, meant for a certain group of people and not for all human 
beings universally. This is a political propaganda perpetuated by the developing world leaders with their vested interests.

Bhalla (1991) stated that one of the significant aspects of contemporary international relations is the importance attached to the promotion and protection of human rights. Institutions of grant importance spend an increasing amount of their time on questions of human rights and an increasing sector of the membership of international institutions accords human rights question a priority that in many cases even exceeds questions of peace and security. The increasing inter dependence of modern world economically, politically, technologically and strategically has made concern for human rights a major international fact.

Forsythe (1989) said that problems of human rights have been viewed in different ways, especially the question of how much emphasis should be placed on each category of rights of civil, political, economic or social and cultural. Arguments have been advanced in favor of economic and political rights on the other hand; it has been argued that civil and political rights are preconditions for the realization of economic and social rights.

In 1977, UNESCO mentioned that the human rights approach is not surprising when it is remembered that at least half of the population of the globe are effectively deprived of their basic human rights, the up routed the oppressed, the illiterate, the unemployed, the starving and soon.

Brounlie (2006) narrates that the United Nations has set some standards. The Universal Declaration of Human Rights and charter of United Nations provide full explanation of every basic human rights with complete implementation of these rights.

The Universal Declaration of Human Rights was adopted by the United Nations general Assembly in 1948. It urges member Nations to promote a number of civil, economic and social rights, asserting these rights as part of "foundation of freedom, justice and peace in the world" (Henkin, 1987). The declaration was the first international legal effort to limit the behavior of states, press, for their citizens following the model of rights and duties. The Declaration was framed by members of the Human Rights Commission, with former First Lady Eleanor Roosevelt as chair, discussed an International Bill of Rights in 1947.

The members of the Human Rights Commission did not immediately agree on the form of such a bill of rights, and whether, or how it should be enforced. The commission proceeded to frame the Universal Declaration of Human Rights and accompanying treaties, but the Universal Declaration of Human Rights became the priority. Professor John Humphrey (Canadian Professor of Law) and Mr. Rene Cassin (Lawyer in France) make the cross national research and the structure of the document respectively, where 
the articles of the Declaration were interpretative of the general principle of the preamble (Henkin, 1987).

The document was structured by Cassin to include the basic principles of dignity, liberty, brotherhood and equality in the first two articles, followed successively by rights pertaining to individuals; rights of individuals in relation to each other and to groups; spiritual, public and political rights; and economic, social and cultural rights (Ball \& Gready, 2006).

The Universal Declaration was divided into treaties, a covenant and civil and political rights and another on social, economic and cultural rights due to questions about the relevance and propriety of economic and social provisions in covenants on human rights. Both covenants begin with the right of people to self determination and the sovereignty over their natural resources. This debate over whether human rights are more fundamental than economic rights has continued to the present day.

Sulibian (2003) a said that now the human rights have been promoted through legal standards, to vast degree human rights have been protected in fact, If we take ten of the most fundamental instruments of human rights, we find that there is an array of measures amiable for the implementation of human rights. He suggests that international area is the most obvious area for the promotion of human rights.

Mumtaz, \& Shaheed (1987) analyzed, the role and status of women are not isolated social phenomena, and women's struggle do not take place in a vacuum. Both are determined, enhanced or impeded, by the social, political and economic development of a people's history. The Islamization campaign in Pakistan to curtail women's rights and to resist this, women's movement has been formed and both are the result of ongoing processes. Noam Chomsky (1978) discussed that Western intelligentsia continue, in a significant measure, to exploit the substantial freedom that they enjoy to construct the system of beliefs that is required to defend privilege and power and justify its exercise, as the poor and oppressed of the world seek ways to take this future in their own hands.

William Talbott (2007) said that basic human rights are the rights necessary to enable all people to develop and exercise autonomy to become the authors of their own lives, Human Rights with normal cognitive, emotional and behavioral capacities, have the ability to become autonomous. He stated that in order to identify the basic human rights that should be universal, it is necessary to investigate the conditions necessary for autonomy. 
Ali (2011) wrote that much awareness has been created concerning the rights of women throughout the globe and Pakistan. In a domestic setup the women have their role and they also face hazards of social behaviours. The education plays a vital role to maintain dignity of women and the economic circumstances also have their own effect.

Most of the studies related to human rights stress that human being is a social creature and wants to live in a society with the protection of its basic human rights. Islam has emphasized so much on basic rights of parents. Other religions as compared to Islam have not discussed about the rights of parents although it is an important aspect of human life. Other religions has not explained the basic rights of humans in detail. If we compare the human rights charter and Islamic teachings there are a lot of similarities between the two. Therefore, we can argue that Islam gave the concept of Human Rights the initially in the world. Women enjoy a special status and protection in the rights given by Islam. In fact, Islamic law (Shariat) provides a sound cover to women against all sorts of exploitation and safeguard them from exploitation of the society.

\section{Women Rights in Pakistan (Interpretation)}

The constitution (1973) is the supreme law of the Islamic Republic of Pakistan and all laws passed should be in line with the constitution. The constitution has undergone various amendments which have weakened the guarantee it provides for equal rights; Articles 8 to 28 describe the fundamental Human Rights.

All citizens (men and women) are guaranteed: freedom of speech, expression, freedom of to assemble peacefully, freedom of association and the right to move freely throughout Pakistan to reside any part of the country. The dignity of men and women and the privacy of home are declared inviolable. Every man and woman is guaranteed the freedom to enter upon any lawful profession or occupation or to conduct any lawful trade or business.

The constitution grant fundamental rights to safeguard against discrimination in services on the ground of race, religion, caste, residence, sex. However, special provisions could be made for women and children.

The Human Rights Commission of Pakistan is an independent, non-profit organization founded in 1987.It is voluntary, non-governmental organization registered under the societies Registration Act (XXI of 1860). Its mission is to implement the Universal Declaration of Human Rights and other related charter, covenants, protocols, Resolutions, and internationally adopted norms. It cooperates with aid national and international groups, organizations and individuals in protection of Human Rights charter and to take 
appropriate action to prevent violations of human rights and to provide legal assistance to victims of those violation The Human Rights Commission (2015) noted:

"A proliferation of instances of the so called honor killing, rape, acid, attack, domestic violence and assaults against women was evident. Infants bore the brunt of the prolonged drought in Tharparker, where over 650 paid with their lives for the apathy in high places"

Pakistan lagged most Asian countries in educating a significant proportion of its children especially girls. The health care system, already among the weakest in South Asia, continued to deteriorate at a fast pace. Targeted attacks on healthcare workers and their security escorts posed a serious challenge to what some already considered Pakistan losing battle against polio. "In 2014 the high incidence of polio in Pakistan broke the country's own previous record. Child and bonded labor remained rampant and laborers including children, continued to work in hazardous conditions (The State of Human Rights, 2015).

Throughout the history of Pakistan women have always been deprived of a part of their human rights. According to international Human rights law, the ruling principle is equality of man and women. Due to their human being, no difference should exist between them and the principle of equality should rule. This is an important principle from the viewpoint of observing human rights for women. Women have economic, socials political and judicial rights which were considered especially for men in social customs and traditions throughout the history.

The adoption of women rights in the category of human rights is linked with the United Nations Convention on the Elimination of all forms of Discrimination against Women, in December 1979, which became law in September 1981 (Baxi, 2009).

To modify the social and cultural pattern of conduct of men and women with a view to achieve the elimination of prejudices and customary and other practices which are based on the idea of interiority or the superiority of either of the sexes or on stereotypical roles for men and women. The rights of women are often violated not in the civil and political sphere but in the realism of culture, customs and practices as well (Baxi, 2009).

There are considerable differences between countries in regard to their philosophy concerning women and the actual enjoyment of basic rights by women, and these are inextricably linked with the culture and values of furthering the rights of women is of particular importance and should be considered in relation to their central role in regard to the family and the welfare of the children. There is a need to encourage and prepare women to accept new and wider responsibilities in society. This can be done through educational programs and the positive role by women's organizations. Although women 
constitute a majority of the population, there is no society in which women enjoy full equality with men. The UN has always advocated that the promotion of the human rights of women must eliminate all forms of gender based discrimination and enable them to participate fully in all spheres of civil and social, economic and political cultural life.

In Pakistan, laws governing family and marriage were reformed under the military regimes of general Ayub Khan (1958-69). Moreover, women's access to labor market and to education improved somewhat in the context of government economic reforms. To follow western liberal traditions, Ayub Khan cast doubt on the world view of religious leaders (ulemas) whom he considered retrogressive. Ayub Khan invoked Islam, in response to the rising tide of Bengali nationalism in East Pakistan (Now Bangladesh) in 1960s.

In 1965, the president Ayub gained unexpectedly the support of religious leader to context the candidacy of Ms. Fatima Jinnah (woman) in the name of Islam. Islam was manipulated in Pakistan for political ends. Some religious leader, who had denounced the participation of women in political life, endorsed the candidacy of Ms. Jinnah for reasons of political exigency (Burki, 1991).

During Zulfiqar Ali Bhutto's regime (1971 to 1977), conditions for women were, however, improved significantly. During this period, the equality of men and women was recognized in law, for the first time in the history of Pakistan. The number of women in services grew considerably. A commission on the status of women in Pakistan was established in July 1976. The commission gave its report after eight months indicating legal reforms, but the report was never ratified by the National Assembly, nor it was made public. Ziaul Haq, took over the power in 1977 and a number of rights which had been granted to women during Bhutto's regime were compromised. Ziaul Haq used Islam for political purpose.

Ziaul Haq (1977-1985) suspended fundamental rights entrenched in the constitution, including rights for guaranteeing the equality of men and women before the law. He advocated to reinstate in the country "the moral purity of early Islam" and to return to the "The sanctity of the chardivari", that is the confinement of women within the four walls of the home. He legislated the Hadood Ordinances, the Qanun-e- Shahadat (law of evidence) and the Bill concerning Qisas-e- Diyat (Retribution), which help to deteriorate the status of women in Pakistan (Jahangir \& Jilani, 2003). Later on during Benazir Bhutto, and Nawaz Sharif regimes the status of Women's rights remained skeptical except during the 90 days rule of the Interim Government of Moin Qureshi in 1993, both private and public media condemned the discrimination against women in Pakistan and particularly discrimination related to the Hudood Ordinance (Matsui, 1990). 
The United Nations adopted the standard and principles concerning women's rights in the first 30 years of its existence of the various international principles pertaining to the status of women, on political rights of women and the conventions on the abolition of slavery. In spite of the recommendations of various Pakistani and international Human rights organizations, Pakistan has yet not ratified the Convention on the elimination of all forms of discriminations against Women, which unites in a single instrument (United Nation Centre for Human Rights, 1993).

The constitution of Pakistan (1973) was substantially modified in the context of Islamization of the society under the regime of Ziaul Haq (1979 to 1988). However the current constitution recognizes the equality of men and women before law and prohibits all forms of discrimination, especially sexual discrimination, within the civil service and grants women the rights to participate fully in all activities in the national arena (Patel, 1979). However, many women's rights observers and activists believe that these constitutional clauses do not provide Pakistani women with equality in the reality of life. For example, the commission setup by the government in 1955 incorporated many recommendations into the Muslim family Law Ordinance (1961). Under law the husband must obtain the prior consent of his first wife before marrying a second wife, but actually that is not practiced in the society.

Under the law, all marriages must be registered, which eliminates the much abused customary practice of divorce by declaration, that is, a divorce obtained by uttering the word "Talaq" (Divorce) three times. Moreover, the law grants women the right of divorce on a condition that a clause to this effect was written into the "Nikah Nama" (Marriage contract), at the time of marriage. Because a high rate of illiteracy in women, they are not aware with this clause. The rate of literacy for women must be encouraged by formulating policies by the government.

Article 25 (2) of the constitution of Pakistan mandates that there shall be no discrimination on the basis of gender alone. Further, Article 34 makes it incumbent upon the state to take up to ensure full participation of women in all sphere of national life. It is a fact that women are human being like men and women's rights are human rights. Human rights of women has been defined as collective rights for a women to be seen and accepted as a person with the capacity to decide or act on her own behalf and to have equal access to resource and equitable social, economic and political support to develop her full potential, exercise her right as a human being and to support the development of others.

Violence is an action or policy or an attitude that causes bodily or mental injury and debars or dehumanizes a person. The violation of the rights of women is a human rights violation of her body and her right as a person. The violation of women's rights takes 
many forms such as sexual or physical assault and harassment, female feticide and infanticide, female circumcision and dowry deaths, Sati, wani and denial of her autonomy and authority over her body.

Women rights are very important, these right should be same for all woman no matter what their background is their race, origin etc. People deserve to be accepted like we are. They have their rights which are the same as ours and should be respected.

The Federal Government of Pakistan established the full fledge, Ministry of Human Rights in November 2008. While the announcement of the creation of National Human Rights Commission was made in 1993 in the tenure of the caretaker government, need was felt for establishment of Human Rights Cell. The cell was established in December 1993, Ms. Banazir Bhutto, the former Prime Minister on ardent advocate for democracy and for human rights of the most vulnerable sections of society, particularly children, and minority rights, upgraded this cell to the status of an independent Ministry in November 1995. However, in December 1996, due to serious financial crisis in the country, the ministry was degraded to Human Rights Wing, which was attached to the Ministry of Law and Justice making its the Ministry of Law, Justice and Human Rights. The same wing was upgraded to the level of a division in November 2007 and then to the current Ministry of Human Rights.

Pakistan is an Islamic State and follow its path according to Islamic teaching. Islam introduced fundamental reforms to customary law and introduced rights for women in marriage, divorce and inheritance, by providing that the wife, not her family, would receive a dowry from the husband, which she could administer as personal property, the Quran made women a legal party to the marriage contract. Islam has given the right to women to marry man according to her choice. The Quran says:

"And they (women) have right similar to those (of men) over them in Kindness, and men are a degree above Allah is mighty, wise" (Al Qur'an, 2:228).

The Quran protect women and their right for the prevalent misguided stereotypes of women and to give them a respectable position in society. Good teachers us that superiority in this presence is a not on gender, but rather on one's fear and respect of Allah faith, good character, devotion and dedication. Islam accept the equality of men and women.

Human rights are interdependent and inter related. Each contributes to the realization of a person's human dignity through the satisfaction of his or her development physical, psychological and spiritual needs. The fulfillment of one right often depends, wholly or in part, upon the fulfillment of others. For instance, fulfillment of the right to health may 
depend in certain circumstances, on fulfillment of the right to development, to education or to information.

It we see the Pakistan's laws on Human Rights, we can take guidance from father of the Nation Muhammad Ali Jinnah, in which in his presidential address to the constituent Assembly of Pakistan in 1947, he said:

"History shows that in England, conditions some time ago, were Mule worse than those prevailing in India today. The Roman Catholics and the protestants persecuted each other. Even now there are some states in existence where there are discriminations made and bars imposed against a particular class. Thank God, we are not starting in those days. We are starting in the day where there is no discrimination, no distinction between one community and another, no discrimination between one caste or creed and another. We are starting with fundamental principle that all citizens and equal citizens of one state" (J. J. Ziegler, 2011).

Equal rights for women, and full participation for women in all fields of social life are "a necessity for the full and Complete development of a country, the welfare of the world, and the cause of peace" (UNDEDAW, 1980).

An appeal contained in the Declaration on race and racial prejudice, unanimously adopted by the General conference of UNESCO (1978) needs to be in this context " The mass media and those who control or serve them as all organized groups within national committees, are urged with due regard to the principles embodied in the Universal Declaration of Human Rights, particularly the principle of freedom of expression to promote understanding tolerance and friendship among individuals and groups and to contribute to the eradication of racism, racial discrimination and racial prejudice, in particular by refraining from presenting a stereotyped, practical, unilateral or tendentious picture of individual and of various human groups" (Many Voices One World, 1980).

The violation of human rights, the most systematic, widespread and entrenched is the denial of equality to women. There is no country in the world where women have achieved although making up half or more than half of the population, women are treated as a minority group, disadvantaged and powerless often the burdens of poverty, unemployment and the educational backwardness weigh more heavily on woman than on men (Many Voices One World, 1980).

More than two thirds of the illiterates in Pakistan and the education given to girls as compared to boys tends to be inferiors and is more often curtailed at early age. Women need free access on equal terms to education, social participation and communication the 
social, political and religious problem of the country. But in Pakistan, this access is hindered by traditions, by prejudices based on social customs or sometimes on religion by discriminatory laws in the country, and also by imposing on women a imbalance shame of responsibility for care of the home and work on agricultural land, as the country rural area is dependent on women workfare and even in urban set up, they hold tremendous responsibilities.

Lack of education is a major hindrance to choice of occupation, women hardly gain an opportunity for gain economic independence, social security and proper consciousness of their own value. Public attitudes regarding the role of women in society the country are major determinants in deciding the status of women. Women are confined to domestic sphere or also as secretaries, assistants and similar rules as compared to those of men. Even in domestic and personal situations, women seems as incapable of making decision without male guidance. The Report by the International Commission for the study of communication problems stressed:

"The achievement of full equality for women is a matter of justice and human rights; it is also necessary so that society can mobilize all its focus for social progress and especially for efforts of development. The world cannot afford to waste the great resources represented by the abilities and talents of women. This is the thought that should be constantly in the minds of those responsible for decision in communication” (Many Voices One World, 1980).

In a seminar on "self employed women in Pakistan" organized by center of excellence for women's studies, University of Karachi, Dr. Nasreen Aslam Shah stressed that women need to be strong to fight for discrimination they face. Domestic violence and child abuse are the major issues that need to be addressed for a better and peaceful society. The role of women in the development of country should not be ignored as they are a key segment of our society. The speakers advocated the need of a safe atmosphere in the country, in which women can get education and also fulfill their duties without any fear. The seminar urged the government to take measures to promote technical and vocational education among women so that they could be empowered financially. The government should create awareness of women protection laws through media so that women in all parts of Pakistan could known their rights. In this context, the recently passed bill pertaining to protection of women against harassment was commendable (Express Tribune, 2016).

The principal of fundamental rights guaranteed in the constitution of Pakistan (1973), which says all citizens are equal before the law and entitled to equal protection of law. No person should be deprived of life or liberty save in recordance with the law. There should be no discrimination on grounds of religion, race, caste, sex, or place of birth with regard to access to places of public entertainment, recreation, welfare or utility. All forms 
of slavery, servitude, forced labour, torture or cruel or inhuman treatment or punishment were declared illegal. The constitution guarantee non-discrimination in respect of women and children. The ruling principle is the equality of man and women. Due to their being human, no differences should exist between them and the principle of equality's should rule. Women have economic, social, political and legal rights, which are considered especially for man in traditional customs. The United Nations Convention an the Elimination of All form of Discrimination against Women was adopted in December 1979 and became (lord) in September 1981. Article 25 (27 of the constitution mandates that there shall be no discrimination on the basis of sex alone. Mention further article 34 makes it incumbent upon the state to take step to ensure full participation of women in all sphere of life. The constitution grant human rights of women, collective rights for men and women, and women are accepted as a person with the capacity to decide or act on her own behalf and have equal access to resources of the country. The violation of the rights of women's right is human rights violation of her body and her right as a person. Gender justice remain a far cry all over the world as has been highlighted by Prophet Muhammad (Peace be Upon Him) long time ago.

\section{Conclusions}

In order to follow the example of Prophet Muhammad (Peace be upon him) we should see how he treated women. He never lifted a finger at any of his wives or daughters throughout his life. He said "the best of you are those who are the best to their wives, and I am the best amongst you, to my wives" (Ahmed, 2016).

Once a man's complaint that his wife became violent with him, Prophet Muhammad (Peace be upon him) advised him to bear his wife's treatment with patience. Prophet Muhammad (Peace be upon him) consulted Bibi Fatima regarding Hazarat Ali's marriage proposal for her. In Pakistani society mistreats wives, furring them physically and mentally, cutting off their nose and ears, disfiguring them by throwing acid on their face, Kidnapping and raping them and even killing girls if they express their preference in the choice of husband are a common feature.

In Islam, marriage is a social contract between man and woman. At the time of Nikah, the bride is asked if she is willing to marry the groom, meaning that she has a choice. A forced marriage is un-Islamic and haram or forbidden, while a talk (Divorce) is halal or permissible, if a woman does not want to live with a man, for any reason, that is her prerogative. Domestic, psychological and verbal violence, economic abuse are common in the society. Woman are harassed by men who are trying to harm them because of their proposal had been refused.

The aggrieved women shall be proofed under the criminal procedure code, 1998. 
Nilofar Ahmed (2016) in the Dawn refers specifically that sometimes people Quote from Surah Al Nisa, in the Quran to set their own purpose. Here the word "qawwam" mean 'protector',' provider' and 'supporter', but it is traditionally translated as 'ruler' and 'lord'. The word 'mushur' which can be translated as 'disloyalty' is often translated as 'disobedience'. Besides the father and husband, 'arrijall' or man as a whole including the government are responsible as' protector' and 'supporters' of women.

Prophet Muhammad (Peace be upon him) said the most perfect man in his faith among the believers is ' the one whose behaviour is the most excellent' and the best of you are 'those who are the best for their wives'. Good manners and good behaviour are frequently emphasized both in the Quran and Hadith. Lack of civility and good manners in Pakistan's society is rampant and this is partly due to the lack of education and Islamic teaching and also to the examples set by religious and political elites. If our opinion leaders become those who preach hatred against women and people with different views and who incite superficial emotions based on irrationality, people will become crude, callous, disrespectful, intolerant and be left with little dignity. Pakistan need a greater commitment to accelerate efforts towards gender equality. We have different laws and initiatives for the protection of women's rights including the Sindh Child Marriage Restraint Act, 2013, the domestic violence (Prevention and protection) Bill, 2013, the protection against Harassment of women at workplace 2010 and the Anti Women practices Act, 2011. But, we still lack the infrastructure to implement the laws. In spite of the existence of laws, there is rampant disregard of women right in society. There is need for eliminating discriminatory policies and attitudes against woman.

The Quran repeatedly stresses on equality of men and women by saying that human are created from on soul (Al Qur'an, 4:1). While the Holy Qur'an emphasizes on the equality, it also reorganize the diversity among human kind. for example indicates that Allah has purposefully created different comities, or else. He could have made all humankind one community. For example in one verses a Allah Says' mankind we have created you male and female, and made you into nations and tribes, so that you may know one another" (Al Qur'an, 49:13). Similarly, in another verse, the Quran says "To each among you have. We prescribed a law and an open way, If Allah had so willed, He would have made you a single people" (Al Qur'an, 5:48) the Quran also teaches "one to tolerate differences and not to impose one's faith on others" (Al Qur'an, 2:256). Likewise, many examples can be in the teachings and life of Prophet Muhammad (Peace be upon him) that stress as the unity of human being and respect for women. The prophet (Peace be upon him) repeatedly reminded humankind to be respectful and helpful to each other. We can conclude that there are plenty of messages in the Quran and in the teachings of Prophet (peace be upon him) that stress on the respect of women in a society. 


\section{References}

Ahmed, Nilofar (2016). Women's Dignity, Daily Dawn, March 25, 2016, Karachi, http://www.dawn.com/authors/388/nilofar-ahmed

Al Qur'an 2:228.

Al Qur'an, 2:256

Al Qur'an, 4:1

Al Qur'an, 49:13

Al Qur'an, 5: 48

Al, Quran, 4:34

Ali, Zaka (2011). The Constitution of Islamic Republic of Pakistan (1973). Karachi; The Ideal Publishers, Karachi.

Ball, Olivia \& Gready, Paul (2006). The No-Nonsense Guide to Human Rights, New Internationalist, Oxford, p.34.

Baxi, Upendra (2009). Human Rights in Post Human World, Critical Essays, Oxford University Press, pp.16-18.

Bhalla, S.L. (1991). Human Rights: An Institutional Framework for Implementation; Docta Shelf.

Brounlie, Ian, (2006). Basic Documents on Human Rights; London: Oxford University Press.

Burki, Shahid Javed (1991). The Continuing Search for Nationhood, Colombia: Westview Press, p.34.

Celebrating Working Women: Home-Based Workers Display Handcrafts at KU Event, March 9, 2016, The Express Tribune, Karachi, http://ribune.com.pk/story/1061923/celebrating-working-women-home-basedworkers-display-handcrafts-at-ku-event/ 
Chomasky, Noam's (1978). Human Rights and American Foreign Policy, New York: Spokesman Books.

Dawn, March 25, 2016.

Figures obtained from Annual Plan 2015-15, Islamabad: Planning Commission, Ministry of Planning, Development and Reform, P.58, http://www.pc.gov.pk/

Forsythe, D. P., \& International Political Science Association. (1989). Human Rights and Development: International Views. New York: St. Martin's Press.

Henkin, Louis (1987). The International Bill of Rights: The Universal Declaration and the Covenants, International Enforcement of Human Rights, Jolowicz, pp.9-10.

J. J. Ziegler (2011). Under the Cross, http://www.catholicworldreport.com/Item/ 729/under_the_cross.aspx

Jahangir, A. \& Jilani, H. (2003). The Hadood Ordinance: A Divine Sanction; Lahore: Sang-e-Meel Publications, pp.188-89.

Many voices one world, New York: UNESCO, 1980, pp.188-89. http://unesdoc.unesco.org/images/0004/000400/040066eb.pdf

Matsui, Yayory (1990). Women's Asia, London: Zed Books, p.67.

Mumtaz, Khawar \& Shaheed, Farida (1987). Women of Pakistan Two Step Forward one Step Back, India: Vanguard Book Ltd.

Patel, Rashida (1979). Woman and Law in Pakistan; Karachi: Faiza Publishers, pp.200-01.

State of Human Rights in 2014 (2015). Human Rights Commission of Pakistan, Lahore: U.B Printers, pp.1-4.

Suliban, A. (2003). Human Rights Complaints System - International and Regional; Deep and Deep Publications Ltd.

The Constitution of Pakistan 1973 (1997). Karachi: Pakistan, Law House.

Tilb H, William J. (2007). Which Rights should be Universal; London: Oxford University Press. 
UN Declaration on the Elimination of Discrimination against Women (1980). Images of the World; New York: UNESCO, p.189. http://www.ohchr.org/Documents/ProfessionalInterest/eliminationvaw.pdf.

UNESCO (1977). Human Rights Aspects of Population Programs, Paris.

United Nations Center for Human Rights (1993). International Instruments; Chart of Ratifications as at January 31, 1993, United Nations; New York: p.371.

Dr. Abida Perveen is an Associate Professor and Director in the Sheikh Zayed Islamic Center, University of Karachi. 